\title{
NEWS and ANNOUNCEMENTS
}

An indispensable new Guide to the archives, libraries, and research centers for the history of the European working class has just been published: (Dieter Dowe (ed), Führer zu den Archiven, Bibliotheken und Forschungseinrichtungen zur Geschichte der europäischen Arbeiterbewegung, Bonn: Verlag Neue Gesellschaft, 1984, $48 \mathrm{DM}$ ). Dowe has assembled valuable information about these institutions - "from the Atlantic to the Urals"-which contain primary and secondary materials about the various orientations of the working-class movement: socialist, social-democratic, communist, anarchist, libertarian, and Christian. Organized alphabetically by country, the following vital information is provided: address, year of origin, director, major scholarly orientation, publications, conferences, international associations, strength and size of library holdings and archives, and information about the operations of the institution. An addendum lists the leading (140) state archives and major (450) national, university, and other European libraries. For Europeanists in labor history this is a long-awaited research aid.

Haymarket Scrapbook: A call for articles, short sketches, translations and suggestions. To mark the centennial of the most world-reverberating event in American labor history, the Charles H. Kerr Publishing Company intends to bring out a compilation tentatively titled Haymarket Scrapbook. This anthology will focus not so much on recapitulating either the actual Haymarket incident, or the trial, but rather on the vast and enduring influence Haymarket has exerted in the U.S. and around the world. The Haymarket Scrapbook will include reprints of hard-to-find original documents, translations heretofore unavailable in English, and original articles by contemporary labor activists and historians. It will be divided into four principal sections: (1) The setting: Brief texts summarizing the economic, political, and cultural situation in the U.S., especially in Chicago, in the 1880s; (2) The Haymarket martyrs and their milieu: The martyrs, their friends, their unions, and other groups to which they belonged, their ideas, the activity they engaged in, the publications they edited and wrote for; (3) The defense: Short biographical sketches of major and minor participants in the defense including Joseph Dietzgen, Ezra Heywook, Lizzie Holmes, Henry Demarest Lloyd, Clarence Darrow, John Brown, Jr., Cora Richmond, George Schilling, John Swinton, George Francis Train, and others, also texts on the Haymarket defense in other countries; (4) repercussions: influence of Haymarket on the course of the American labor movement, individuals whose lives were transformed by Haymarket, the origin and history of May Day, echoes of Haymarket in poetry and fiction and art, the 
Haymarket legacy today. For more information about this project, contact Dave Roediger or Franklin Rosemont at Charles H. Kerr Publishing Co., 1740 Greenleaf Ave., Suite 7, Chicago, IL 60626.

The Rockefeller Residency Program in Humanities 1986-87. The Walter P. Reuther Library of Labor and Urban Affairs, Wayne State University, has announced the Rockefeller Foundation Residency Program in Humanities for the 1986-87 academic year. Two full-time residents will be selected. These fellowships are open to junior and senior academic scholars and also to other qualified writers and scholars. They are designed to encourage and facilitate the publication of scholarly humanistic studies based upon the archival sources at the Reuther Library and to contribute to the intellectual life of the community. Deadline for receipt of applications is December 1, 1985. For information and application materials, contact Philip P. Mason, Director, Walter P. Reuther Library of Labor and Urban Affairs, Wayne State University, 5401 Cass Ave., Detroit, MI 48202, (313)577-4003.

Southern Labor, Urban and Community Studies Conference. The Southern Labor Studies Association and the Southern Labor Archives have announced the sixth biennial meeting of the Southern Labor Studies Conference to take place in the Fall of 1986. The conference will return to the campus of Georgia State University and will meet concurrently with the Southern Urban and Community Studies Conference. Paper or session proposals for either conference should be forwarded to the program coordinator, Les Hough, Southern Labor Archives, Georgia State University, University Plaza, Atlanta, GA 30303. Program proposals from all disciplines and on all levels-local, regional, national and international are welcome. 